FACTA UNIVERSITATIS

Series: Physical Education and Sport Vol. 16, N ${ }^{\circ} 1,2018$, pp. 11 - 18

https://doi.org/10.22190/FUPES180122002M

Research article

\title{
EFFECTS OF DEVELOPMENTAL GYMNASTICS ON MOTOR FITNESS IN PRESCHOOL GIRLS
}

\author{
UDC 796.012-053.2
}

\section{Dejan Madić, Milan Cvetković, Boris Popović, Dragan Marinković, Danilo Radanović, Nebojša Trajković}

Faculty of Sport and Physical Education, University of Novi Sad, Serbia

\begin{abstract}
The aim of this research was to determine the effects of developmental gymnastics on motor fitness in preschool girls. This study was performed on a sample of 56 healthy preschool girls that were divided into two groups, a developmental training group and a control group. Motor fitness tests were used from several test batteries: the $20 m$ dash, Obstacle course backwards, Standing broad jump, Arm plate tapping, Seated straddle stretch, Bent arm hang, Sit ups. The basic characteristics of developmental gymnastic training process consisted of station and circuit work and obstacle courses two times a week lasting for $60 \mathrm{~min}$ with intensity around 160-180bpm. After the training intervention, the training group showed significant $(p<0.05)$ improvements in almost all the parameters analyzed (e.g., Obstacle course backwards; Standing broad jump; Arm plate tapping; Bent arm hang and Sit ups) compared with pretest values, with percentages of change and ES ranging from $13.3 \%$ to $48.2 \%$ and 0.64 (moderate) to 1.20 (large), respectively. No significant changes were observed in the control group after the training intervention except for the standing broad jump and arm plate tapping $(p<0.05)$. This study provides evidence on the effectiveness of developmental gymnastics programs for the optimal development of young children's motor fitness.
\end{abstract}

Key words: motor skill, physical activity, preschool, impact

\section{INTRODUCTION}

Physical activity is important for children because of the associated benefits to physical, social and psychological health (Strong et al., 2005). Accordingly, previous research identified a positive effect of organized physical activity on health outcomes such as body composition, skeletal health, aerobic fitness, blood pressure, blood lipids, motor

Received January 22, 2018 / Accepted March 20, 2018

Corresponding author: Nebojša Trajković

Faculty of Sport and Physical Education, University of Novi Sad, St. Lovćenska 16, 21000 Novi Sad, Serbia

Phone: +38121450188•E-mail: nele_trajce@yahoo.com 
development, glucose metabolism, and generally psychological health in youth population (Roth et al., 2010; Bungum \& Vincent, 1997; Butcher, 1983). Existing evidence suggests that physical fitness is an excellent indicator of the health of children and adolescents and is a predictor of health in later life (Cvejić, Pejović, \& Ostojić, 2013). According to Goldfield et al. (2012) between $4 \%-10 \%$ of children aged under five are not meeting physical activity guidelines that suggest engaging in 180 minutes of physical activity a day. Consequently, there is a need for different high intensity programs in order to improve physical fitness in children, and consequently improve their health. Unfortunately, there are limited data on preschool-aged children.

The preschool period is the best time to start implementing various training procedures, particularly challenging ones such as gymnastic exercises, swimming and rhythmical coordination accompanied by music (Stojiljkovic \& Pirsl, 2016; Strong et al., 2005), as well as exercises that include jumps or gaining balance elements (Strong et al., 2005). Developmental gymnastics include gymnastic actions (balance, rolling, step-like action, and flight) and the movement concepts (body, space, effort, and relationship). In developmental gymnastics, children increase the difficulty of skills, vary skills using movement concepts, combine skills in sequences, and perform skills and sequences with partners. Developmentally appropriate skill progressions gradually help children gain the body management skills to perform gymnastic actions and develop muscular strength, endurance, and flexibility (Gallahue \& Ozmun, 2005). Several publications have appeared in recent years documenting the effect of different physical activity programs on motor fitness in preschool. Krneta, Drid \& Jaksic (2014) found significant effects of additional kinesiological treatment on explosive strength (Standing broad jump) and flexibility (Seated straddle stretch) in preschool boys. Another latest solution described by Jakšić (2016) tried to define and analyse the effects of various multi-sport models of exercises on the cognitive, motor and morphological development of preschool children. The aforementioned author concluded that certain morphological characteristics have improved, and that certain motor and intellectual abilities of children from the experimental group have also improved in comparison with the control group. Recent research has documented that a 9-week ball skill intervention was effective in improving ball skills in preschool age girls. These skills as the predictor of motor development were maintained overtime (Veldman et al., 2017). Therefore, early childhood interventions that focus on the development of ball skills in young girls might be necessary. Great effort has been devoted in the study of Radanović et al. (2016). According to the abovementioned study there is a significant impact of motor abilities on performance of all 3 gymnastic elements among primary school girls. Therefore, it is of great importance to constantly improve the motor abilities in preschool years. The aim of this research was to determine the effects of developmental gymnastics on motor fitness in preschool girls.

\section{METHODS}

\section{Participants}

This study was performed on a sample of 56 healthy preschool girls that were divided into two groups. The experimental group $(\mathrm{N}=27)$ consisted of children attending kindergartens, who volunteered for the experiment. The control group ( $\mathrm{N}=29)$ was randomly chosen from the cluster of kindergartens. The average age of the children in the experimental 
group at the beginning of the treatment was $5.08 \pm 0.29$, whereas the children of the control group were aged $5.36 \pm 0.64$. Written informed consents were obtained from the parents of all the children, who gave their assent to participate in the study. All measurements and treatments were performed in accordance with the ethical standards laid down in the Declaration of Helsinki.

Table 1 Body weight status pre- and post-intervention

\begin{tabular}{lrrrr}
\hline & \multicolumn{2}{c}{ Control group } & \multicolumn{2}{c}{ Experimental group } \\
\cline { 2 - 5 } & \multicolumn{1}{c}{ Baseline } & \multicolumn{1}{c}{ Post } & \multicolumn{1}{c}{ Baseline } & \multicolumn{1}{c}{ Post } \\
\hline Body height $(\mathrm{cm})$ & $113.14 \pm 5.47$ & $117.44 \pm 4.88$ & $113.79 \pm 3.87$ & $115.14 \pm 6.12$ \\
Body mass $(\mathrm{kg})$ & $20.68 \pm 2.94$ & $22.22 \pm 3.05$ & $19.90 \pm 2.42$ & $20.20 \pm 2.67$ \\
BMI & $16.10 \pm 1.50$ & $16.06 \pm 1.58$ & $15.32 \pm 1.18$ & $15.18 \pm 1.00$ \\
\hline \multicolumn{4}{c}{ Note: All data are presented in mean \pm SD }
\end{tabular}

\section{Testing procedures}

The set of anthropometric variables and the set of motor variables obtained by the use of the following measurements and tests were analyzed at the beginning of both treatments, and after 6 months. Body height was measured with a fixed measured using anthropometry according to Martin (GPM Anthropometer 100; DKSH Switzerland Ltd., Zurich, Switzerland; $\pm 0.1 \mathrm{~cm}$ ), and body mass with a digital balance (BC1000, Tanita, Japan; $\pm 0.1 \mathrm{~kg}$ ), following the guidelines proposed by the International Biological Program (IBP). Motor fitness tests were used from several test batteries and reliability and factor validity was confirmed for this age group (Bala, Katić, Krneta, 2011). The following test battery was used in motor fitness assessment:

1. $20 \mathrm{~m}$ dash. At the command GO the child that stands behind the start line has to run $20 \mathrm{~m}$ as fast as he/she can to the end of the track $(20 \mathrm{~m})$. The children run in pairs. The score was the time of running, measured in tenths of a second.

2. Obstacle course backwards. The child has to walk backwards on all fours and cover a distance of $10 \mathrm{~m}$, climb the top of a gym bench and go through the frame of the bench. The task is measured in tenths of a second.

3. Standing broad jump. The child jumps with both feet from the reversed side of Reuter bounce board onto a carpet, which is marked in $\mathrm{cm}$. The result is the length of the jump in $\mathrm{cm}$.

4. Arm plate tapping. For fifteen seconds the child has to tap alternately two plates on the tapping board with his/her dominant hand, while holding the other hand in between the two plates. The result is the number of alternate double hits.

5. Seated straddle stretch. The child sits on the floor, leaning against the wall, in straddle position and bows forward as far as possible. A straight-angle ruler is placed down in front of the child and he/she reaches the scale in $\mathrm{cm}$ as far as he/she can. The result is the depth of the reach measured in $\mathrm{cm}$.

6. Bent arm hang. The child under-grips the bar and holds the pull-up as long as he/she can (chin above the bar). The result is the time of the hold measured in tenths of a second.

7. Sit-ups. The child lies on his/her back with his/her knees bent and arms crossed on the opposite shoulders. He/she rises into a seated position and returns into the starting 
position. The instructor's assistant holds the child's feet. The result is the number of correctly executed raises to the seated position (no longer than 60 seconds).

The reliability of these motor tests, as composite tests with 3 items (replications), was previously analysed in a sample of 64 children aged 5-7 years by calculating the intraclass correlation coefficient. Good reliability coefficients were obtained for all these motor tests, as follows: $20 \mathrm{~m}$ Dash ICC $=0.8714$, Obstacle course backwards ICC $=0.96$, Standing broad jump ICC $=0.88$, Arm plate tapping ICC $=0.90$, Seated straddle stretch ICC $=0.97$, Bent arm hang ICC $=0.9113$ and Sit-ups $\mathrm{ICC}=0.92$.

\section{Developmental gymnastics program}

The basic characteristics of experimental training process were the following: organization: frontal work, group work, work with stations, circuit work and obstacle courses; volume: 60 min, frequency: 2 times a week, intensity: according to the usual external signs (sweat, blush, spontaneous breaks), and according to the heart rates (maximum between 170 and 180 per $\min )$.

Table 2 Developmental gymnastics program

\begin{tabular}{|c|c|c|c|c|}
\hline Duration & Organisation & Volume & Frequency & Intensity \\
\hline 6 months & $\begin{array}{l}\text { Frontal work, group } \\
\text { work, work with } \\
\text { stations, circuit work } \\
\text { and obstacle courses }\end{array}$ & $\begin{array}{c}60 \mathrm{~min} \\
\text { per session }\end{array}$ & $\begin{array}{l}2 \text { times } \\
\text { a week }\end{array}$ & $\begin{array}{l}\text { According to the External } \\
\text { signs (sweat, blush, } \\
\text { spontaneous breaks); } \\
\text { Heart rates (maximum between } \\
170 \text { and } 180 \text { per min) }\end{array}$ \\
\hline
\end{tabular}

Structure of training: I) warm up - 15 min. Various movement with changeable speed, exercises that correct and prevent flat-feet), stretching, corrective and preventive exercises from bad posture, proper sense of good performance; II) main part - $40 \mathrm{~min}$. Revision and practice of previous skills, teaching and practice new skills, competitive practice, conditioning; III) cool-down part - 5 min. Stretching, coaching comments, conversation. Every part of the training lesson was run in positive and warm, friendly mood, with proper music (particularly in the introduction and preparation). The gymnastics program with all the details is presented in the doctoral dissertation written by Jakšić (2016).

The control treatment included means of exercising, learning methods, and exercising itself, the purpose of which was to fulfil the requirements of the formal plan and program of preschool institutions. The control treatment was conducted in a small kindergarten gymnasium, typical of all gymnasiums in preschool institutions. The treatment was conducted by two kindergarten teachers, who were not experts in physical education. The gymnasium was modestly equipped with the most necessary props.

\section{Statistical analysis}

Descriptive data were calculated for all the variables. The Shapiro-Wilk tests assessed the normality of distributions. A two-way repeated measure ANOVA $(2 \times 2)$ was used to test for interactions and main effects for time (initial vs. final) and group (training vs. control) on the dependent physical fitness variables. ES was classified as follows: $<0.2$ was defined as trivial; $0.2-0.6$ was defined as small; 0.6-1.2 was defined as moderate; 
1.2-2.0 was defined as large; $>2.0$ was defined as very large; and $>4.0$ was defined as extremely large (Hopkins et al., 2009). Statistical analyses were conducted in SPSS (SPSS, Version 18.0, Chicago; IL). Statistical significance was established a priori at $\mathrm{p}<$ 0.05 to test the hypothesis that the experimental group would be more effective than the control in improving physical fitness measures in children.

\section{RESULTS}

The Shapiro-Wilk test has shown that the data was normally distributed. Values for all motor fitness tests at pre- and post-intervention are presented in Table 3. After the training intervention, the training group showed significant $(\mathrm{p}<0.05)$ improvements in almost all the analyzed parameters (e.g., Obstacle course backwards; Standing broad jump; Arm plate tapping; Bent arm hang and Sit ups) compared with pretest values, with percentages of change and ES ranging from $13.3 \%$ to $48.2 \%$ and 0.64 (moderate) to 1.20 (large), respectively. No significant changes were observed in the control group after the training intervention except for the Standing broad jump and Arm plate tapping ( $\mathrm{p}<$ $0.05)$. Changes were significantly different in favour of the training group compared to control group in the Obstacle course backwards $(\mathrm{p}=0.001 ; \mathrm{ES}=23.7 \%$ vs. $7.1 \%)$ and Bent arm hang $(\mathrm{p}=0.001$; $\mathrm{ES}=48.2 \%$ vs. $-4.9 \%)$.

Table 3 Mean \pm SD results of different parameters before the experimental period (initial) and after the 24-week experimental period (final).

\begin{tabular}{|c|c|c|c|c|c|c|c|}
\hline & & $\begin{array}{r}\text { Initi } \\
\text { (Mean } \pm\end{array}$ & SD) & $\begin{array}{r}\text { Fin } \\
\text { (Mean }\end{array}$ & $\begin{array}{l}\text { al } \\
\pm \mathrm{SD})\end{array}$ & $\%$ diff & $\mathrm{EF}$ \\
\hline \multirow{2}{*}{$20 \mathrm{~m}$ dash (s) } & Cont. group & $5.71 \pm$ & 0.44 & $5.69 \pm$ & 0.67 & -0.40 & -0.035 \\
\hline & Exp. group & $5.48 \pm$ & 0.6 & $5.33 \pm$ & 0.50 & -2.70 & -0.271 \\
\hline \multirow{4}{*}{$\begin{array}{l}\text { Obstacle course } \\
\text { backwards (s) } \\
\text { Standing broad } \\
\text { jump }(\mathrm{cm})\end{array}$} & Cont. group & $30.57 \pm$ & 8.6 & $28.41 \pm$ & 6.90 & -7.10 & -0.277 \\
\hline & Exp. group & $33.86 \pm$ & 7.96 & $25.84 \pm$ & $5.03 * \dagger$ & -23.70 & -1.204 \\
\hline & Cont. group & $99.66 \pm$ & 13.44 & $111.80 \pm$ & $14.15 *$ & 12.20 & 0.879 \\
\hline & Exp. group & $95.07 \pm$ & 19.04 & $107.76 \pm$ & $20.45^{*}$ & 13.30 & 0.642 \\
\hline \multirow{2}{*}{$\begin{array}{l}\text { Arm plate } \\
\text { tapping (freq.) }\end{array}$} & Cont. group & $15.23 \pm$ & 3.11 & $17.14 \pm$ & $2.88 *$ & 12.50 & 0.637 \\
\hline & Exp. group & $14.84 \pm$ & 2.33 & $16.84 \pm$ & $2.47 *$ & 13.50 & 0.833 \\
\hline \multirow{2}{*}{$\begin{array}{l}\text { Seated straddle } \\
\text { stretch }(\mathrm{cm})\end{array}$} & Cont. group & $34.38 \pm$ & 7.69 & $36.19 \pm$ & 7.87 & 5.30 & 0.232 \\
\hline & Exp. group & $40.23 \pm$ & 7.01 & $42.53 \pm$ & 7.60 & 5.70 & 0.314 \\
\hline \multirow{2}{*}{$\begin{array}{l}\text { Bent arm } \\
\text { hang }(s)\end{array}$} & Cont. group & $8.63 \pm$ & 3.54 & $8.21 \pm$ & 5.12 & -4.90 & -0.095 \\
\hline & Exp. group & $9.33 \pm$ & 6.31 & $13.83 \pm$ & $5.57 * \dagger$ & 48.20 & 0.756 \\
\hline \multirow{2}{*}{ Sit ups (freq.) } & Cont. group & $19.83 \pm$ & 10.29 & $22.83 \pm$ & 6.78 & 15.10 & 0.344 \\
\hline & Exp. group & $17.15 \pm$ & 8.84 & $22.61 \pm$ & $7.68 *$ & 31.80 & 0.659 \\
\hline
\end{tabular}

Note: * Significantly different from initial, $\mathrm{p}<.05 ; \uparrow$ Significantly different from control, $\mathrm{p}<0.05$.

\section{DISCUSSION}

The present study assessed the impact of a 6-month developmental gymnastics program on the motor fitness of children aged 5-7 years. The major findings of this study were that 6 months of developmental gymnastic training improved motor fitness, with positive training effects on coordination and strength, as well as on explosive power and 
speed of upper limb movement. In the case of the control group, the changes were less pronounced, but explosive power and speed of the upper limb movement were improved. In contrast to the enhanced physical performance, body composition remained nearly unchanged. Increases in height, weight and BMI are usual for this age group. Similar gains in BMI during 6 months $(0.4$ to $0.8 \mathrm{~kg} / \mathrm{m} 2)$ have been reported in a German reference sample (Kromeyer-Hauschild et al., 2001). Korsten-Reck et al. (2001). In addition, Weintraub et al. (2008) observed significant decreases in BMI z-scores over similar time periods. The intervention chosen by Korsten-Reck et al. (2001) also included educational and nutritional advice and z-score values were initially higher than those in our study. This may partly be responsible for the different BMI trend. The reductions found by Weintraub et al. (2008) in their football group were rather small (2.15-2.06 after 6 months) and BMI zscores were in the range of the pre- and post-values observed in the present study. The estimated average energy expenditure during both training programs was about $700 \mathrm{kcal}$ per week. However, nutrition was not controlled for during the long duration of our intervention period and, therefore, a conclusive statement cannot be drawn.

Children in the intervention group showed significantly better improvements in explosive leg strength, upper body strength and the strength and endurance of the abdominals while positive effects on speed and flexibility did not persist. In that direction, developmental gymnastics can play a significant role as it is considered to be an excellent means for improving and promoting motor and health related fitness (Coelho, 2010). Similar to our study, Roth et al. (2010) have provided evidence that motor skills performance in preschool children can be improved and maintained by an appropriate physical activity program in 4- to 5-year-old boys and girls. Previous studies in children concerning the impact of motor skills on cognitive development and academic performance were based on cross-sectional studies (Haapala, 2013). However, one study showed significant improvement in motor and intellectual functioning of 5-year old children following a preschool intervention program (Bala et al., 2014).

Early childhood is considered an ideal age period for the development of fundamental movement skills (Gallahue \& Ozmun, 2005; Krneta, Casals \& Bala, 2015). In the present study, the noticeable improvements were found for coordination in developmental gymnastics group. This was confirmed in previous research involving preschool children where a gymnastic program developed locomotor and object control skills (Mostafavi et al., 2013).

In conclusion, compared to the control group, the experimental group showed significant improvement in the obstacle course backwards testing of young children. It seems that the developmental gymnastics program significantly contributed to the development of coordination in preschool children. The control group showed improvement in explosive power and speed of upper limb movement. The daily activity of young children consists of play that could have a positive impact on the motor development of young children (Corrie \& BarrattPugh, 1997). However, this impact is lower compared to the impact of purposefully organized exercise programs as the developmental program of the present study.

Some study limitations should be noticed. We did not follow the children's daily unorganized activities and inactivity that could have possible influenced mastering the motor skills and development of abilities. Moreover, as a limitation, the relatively small sample size should be considered. Nevertheless, this study provides evidence about the effectiveness of developmental gymnastics programs for the optimal development of young children's motor fitness. 
Acknowledgement: The paper is a part of the research done within the project 179011.

\section{REFERENCES}

Bala, G., Katić, R., \& Krneta, Ž. (2011). Do kinesiologic activities change aberrant behavior in preschool children?. Collegium antropologicum, 35(4), 1007-1015.

Bala, G., Krneta, Ž., \& Drid, P. (2013). The Effects of Kinesiological Activity on Motor and Intellectual Functioning of Children in Relation to Their Physical Constitution at Birth. Collegium antropologicum, 37(2), 161-169.

Bungum, T. J., \& Vincent, M. L. (1997). Determinants of physical activity among female adolescents. American journal of preventive medicine, 13(2), 115-122.

Butcher, J. (1983). Socialization of adolescent girls into physical activity. Adolescence, 18(72), 753-766.

Coelho, J. (2010). Gymnastics and Movement Instruction: fighting the decline in motor fitness. Journal of Physical Education, Recreation \& Dance, 81(1), 14-18.

Corrie, L., \& Barratt-Pugh, C. (1997). Perceptual-Motor Programs Do Not Facilitate Development: Why Not Play?. Australian journal of early childhood, 22(1), 30-36.

Cvejić, D., Pejović, T., \& Ostojić, S. (2013). Assessment of physical fitness in children and adolescents. Facta Universitatis Series Physical Education and Sport, 11(2), 135-145.

Gallahue, D. L., \& Ozmun, J. C. (2006). Understanding motor development: Infants, children, adolescents, adults. McGraw-Hill Humanities, Social Sciences \& World Languages.

Goldfield, G. S., Harvey, A., Grattan, K., \& Adamo, K. B. (2012). Physical activity promotion in the preschool years: a critical period to intervene. International journal of environmental research and public health, 9(4), 1326-1342.

Haapala, E. A. (2013). Cardiorespiratory fitness and motor skills in relation to cognition and academic performance in children-a review. Journal of human kinetics, 36(1), 55-68.

Hopkins, W. G., Marshall, S. W., Batterham, A. M., \& Hanin, J. (2009). Progressive statistics for studies in sports medicine and exercise science. Medicine and science in sports and exercise, 41(1), 3-13.

Jaksic D. Effects of the Application of Kinesiology Treatment on Motoric, Morphological and Intellectual Dimension in Preschool Children [dissertation]. University of Novi Sad: Faculty of Sport and Physical Education; 2016

Korsten-Reck, U., Kaspar, T., Korsten, K., Kromeyer-Hauschild, K., Bös, K., Berg, A., \& Dickhuth, H. H. (2007). Motor abilities and aerobic fitness of obese children. International Journal of Sports Medicine, 28(09), 762-767.

Krneta, Ž., Casals, C., Bala, G., Madić, D., Pavlović, S., \& Drid, P. (2015). Can Kinesiological Activities Change» Pure «Motor Development in Preschool Children during One School Year?. Collegium antropologicum, 39(1), 35-40.

Krneta, Z., Drid, P., Jaksic, D., Bala, G., Stojanovic, M., \& Ostojic, S. (2014). Effects of kinesiological activity on preschool children's motor abilities. Science \& Sports, 29, S48.

Kromeyer-Hauschild, K., Wabitsch, M., Kunze, D., Geller, F., Geiß, H. C., Hesse, V., \& Menner, K. (2001). Perzentile für den Body-mass-Index für das Kindes-und Jugendalter unter Heranziehung verschiedener deutscher Stichproben. Monatsschrift Kinderheilkunde, 149(8), 807-818.

Mostafavi, R., Ziaee, V., Akbari, H., \& Haji-Hosseini, S. (2013). The effects of spark physical education program on fundamental motor skills in 4-6 year-old children. Iranian Journal of Pediatrics, 23(2), 216.

Radanović, D., Popović, B., Radaković, M., Marković, K.Ž. and Halasi, S. (2016). Impact of motor abilities on performance of gymnastic elements on floor in girls. Acta Kinesiologica, 10(1), 30-34.

Roth, K., Mauer, S., Obinger, M., Ruf, K. C., Graf, C., Kriemler, S., \& Hebestreit, H. (2010). Prevention through Activity in Kindergarten Trial (PAKT): a cluster randomised controlled trial to assess the effects of an activity intervention in preschool children. BMC public health, 10(1), 410.

Stojiljkovic, D., \& Pirsl, D. (2016). Impact of specific exercising on motor abilities development in junior elementary schoolchildren. Acta Kinesiologica, 10(2), 60-64.

Strong, W. B., Malina, R. M., Blimkie, C. J., Daniels, S. R., Dishman, R. K., Gutin, B., ... \& Rowland, T. (2005). Evidence based physical activity for school-age youth. The Journal of Pediatrics, 146(6), 732-737.

Veldman, S. L., Palmer, K. K., Okely, A. D., \& Robinson, L. E. (2017). Promoting ball skills in preschool-age girls. Journal of Science and Medicine in Sport, 20(1), 50-54.

Weintraub, D. L., Tirumalai, E. C., Haydel, K. F., Fujimoto, M., Fulton, J. E., \& Robinson, T. N. (2008). Team sports for overweight children: The Stanford sports to prevent obesity randomized trial (SPORT). Archives of Pediatrics \& Adolescent Medicine, 162(3), 232-237. 
18 D. MADIĆ, M. CVETKOVIĆ, B. POPOVIĆ, D. MARINKOVIĆ, D. RADANOVIĆ, N. TRAJKOVIĆ

\section{EFEKTI RAZVOJNE GIMNASTIKE NA MOTORIČKE SPOSOBNOSTI DEVOJČICA PREDŠKOLSKOG UZRASTA}

Cilj ovog istraživanja bio je da se utvrde efekti razvojne gimnastike na motoričke sposobnosti kod devojčica predškolskog uzrasta. Ova studija je sprovedena na uzorku od 56 zdravih predškolskih djevojčica koje su podeljene u dve grupe, grupu za razvojnu razvojnu gimnastiku i kontrolna grupu. Za testiranje motoričkih sposobnosti korišćeni su testovi iz nekoliko baterija: $20 \mathrm{~m}$ trčanje, poligon natraške, skok u dalj, taping rukom, sed raznožno, vis u zgibu i podizanje trupa. Osnovne karakteristike obuke razvojnog gimnastičkog procesa sastojale su se od rada na stanicama, kružnog rada i od prelaženja prepreka dva puta nedeljno u trajanju od 60 min sa intenzitetom oko 160-180 otkucaja u minuti. Posle programa, grupa za razvojnu gimnastiku je pokazala značajna $(p<0.05)$ poboljšanja u skoro svim analiziranim parametrima u poređenju sa vrednostima pre programa, sa procentom promene i efektom veličine u rasponu od 13,3\% do 48,2\% i 0,64 (umereni) do 1,20 (veliki). U kontrolnoj grupi nije bilo značajnih promena nakon intervencije, osim skoka u dalj I tapinga rukom $(p<0,05)$. Ova studija pruža dokaze o efikasnosti programa razvojne gimnastike za optimalan razvoj motorike malog deteta.

Kljuĉne reči: veštine, fizička aktivnost, predškolski uzrast, uticaj 